China Perspectives

2009/4 | 2009

Religious Reconfigurations in the People's Republic of China

\title{
Religious Revival and Exit from Religion in Contemporary China
}

Benoît Vermander

\section{(2) OpenEdition}

\section{Journals}

Édition électronique

URL : http://journals.openedition.org/chinaperspectives/4917

DOI : 10.4000/chinaperspectives. 4917

ISSN : 1996-4617

Éditeur

Centre d'étude français sur la Chine contemporaine

Édition imprimée

Date de publication : 31 décembre 2009

ISSN : 2070-3449

\section{Référence électronique}

Benoît Vermander, "Religious Revival and Exit from Religion in Contemporary China », China

Perspectives [En ligne], 2009/4 | 2009, mis en ligne le 01 décembre 2012, consulté le 28 octobre 2019 URL : http://journals.openedition.org/chinaperspectives/4917; DOI : 10.4000/chinaperspectives.4917

(c) All rights reserved 
C

Religious Revival and Exit from Religion in

Contemporary China

\author{
BENOÎT VERMANDER
}

This paper examines both the revival of religious organisations and practices in China and what could be coined the "exit from religion" exemplified by the loss of religious basis for social togetherness and the instrumentalisation of religious organisations and discourse. It argues that "revival" and "exit" taken as a twofold phenomenon facilitate an understanding of the evolving and often disputed nature of China's religious sphere throughout history as well as the socio-political stage that the country is entering.

$\mathrm{T}$ he study of religion in the Chinese context confronts some basic problems: how relevant is the term "religion," borrowed from Western languages via Japanese, in referring to the social forms examined? ${ }^{(1)}$ Even if one chooses to speak of a "religious sphere," can Western concepts turn up anything but largely misleading analogies in describing mental and social structurations, ${ }^{(2)}$ even when the concepts are specifically tailored to take Chinese realities into account? ${ }^{(3)}$ But then, which terms and what categories should be used to consider phenomena usually classed under Western "religious studies"? Conversely, would too narrow a focus on lexicographical matters not lose sight of universal elements in Chinese religious experience and manifestations, thus blocking the way to a comparative work? Further, to what extent do official designations of authentic and "acceptable" religious forms inform or distort our perception of Chinese religious activities in the spontaneity of social manifestations? Such questions can be expanded and pursued, illustrating the basic difficulties faced in any study of "religion in China."

\section{Religion in China: Demography and ethnography}

\section{Regulating and controlling religious practice}

It must be noted that from 1949 until now, only five religious forms have enjoyed legal recognition, and that each of them is "structured" by an association that acts as a conveyor belt between civil society and the party-state whose policies and instructions it transmits. ${ }^{(4)}$ Further, the State Administration of Religious Affairs ${ }^{(5)}$ at the central, provincial, and local levels functions as a sort of "ministry of religion" with extensive powers. Right from the start of the Communist regime, "heterodox cults" and "superstitions," as distinct from "religions," were officially banned, the former often subject to systematic repression, as illustrated right from 1951 by the violent crackdown on Yiguandao. This preliminary observation already points to a framework of understanding. The system in operation introduces a double rupture, while retaining the possibility of safeguarding a "continuum" for the religious sphere:

1. Joël Thoraval, "Pourquoi les 'religions chinoises' ne peuvent-elles apparaître dans les statistiques occidentales?" (Why "Chinese religions" elude Western statistics), Perspectives chinoises, no.1, March 1992, pp. 37-44; Vincent Goossaert, "1898: The Beginning of the End for Chinese Religion?", Journal of Asian Studies, 65(2), 2006, pp. 307-336.

2. Liu Xiaogan, cited by Fan Lizhu, describes as "inverse analogical interpretation" Chinese researchers' practice of applying a Western concept to understand their own belief systems, thus going against the grain of Chinese philosophies right from the first century $A D$, which used familiar concepts such as those of Dao to take into account imported Buddhist notions. See Fan Lizhu, "The Dilemma of Pursuing Chinese Religious Studies in the Framework of Western Religious Theories," Fudan Journal of the Humanities and Social Sciences, 2(2), June 2009, pp. 29-48, especially p. 30.

3. Fan Lizhu notes that C.K. Yang's famous concept of diffused religion to explain the specificity of social forms among China's religious orders has been translated into Chinese often with the connotation of "dispersed" (sankaide), "enlarged" (kuosanxing), "spread" (misanxing), or "distributed" (fensanxing) (Fan, art.cit., p. 38).

4. The "Three-Self Patriotic Movement of the Protestant Churches" was founded in 1954, the Chinese Buddhist Association in 1955, and Islamic, Daoist, and Catholic associations in 1957. The structures may be more complex than this quick summary would suggest. Strictly speaking, the Protestant church is formed by the "China Christian Council " (founded in 1980) and the aforementioned "Patriotic Committee." The relationship between the "official" Chinese Patriotic Catholic Association and the Chinese Catholic Bishops Conference is of the same nature.

5. Previously known as the Bureau of Religious Affairs. 
a rupture between recognised and unrecognised religious forms (regardless of the latter's degree of institutionalisation); and within recognised religions, a rupture between groups and personalities participating in structures established by the party-state and those shunning them. However, in actuality there is less of a rupture than a "continuum" governed by a variety of strategies adopted by different actors as regards the degree of their inclusion in the official apparatus (from total integration to dissidence, with all the stages in between). Article 36 of the PRC Constitution ${ }^{(6)}$ stipulates that:

Citizens of the People's Republic of China enjoy freedom of religious belief. No state organ, public organisation or individual may compel citizens to believe in, or not to believe in, any religion; nor may they discriminate against citizens who believe in, or do not believe in, any religion. The state protects normal religious activities. No one may make use of religion to engage in activities that disrupt public order, impair the health of citizens or interfere with the educational system of the state. Religious bodies and religious affairs are not subject to any foreign domination.

Public control, individual freedom of belief, designation by the state of beliefs and their manifestations deemed "normal," a strict national framework assigned to religious organisations - such are the principles set out.

Barring the 1966-1979 period, the continuity of the regime's legal and ideological framework for dealing with religion prevailed over the changes introduced. The legal framework was set out in 1982, but the principles therein had been adopted right from the early 1950s (a notable exception was the affirmation in 1982 that the elimination of religion was the longterm objective). A quiet change occurred at the turn of the century: the crackdown on "evil cults" from 1999 targeting Falun Gong strengthened the position of state-approved religious forms. It was a change, not rupture, to the extent that religion had been functionalised by the Chinese government, in line with the development of the reform and opening policy, as subordinate purveyors of morality and as part of the social framework and international opening. However, while recognising the positive social role religion could play, there was from then onward a prudent acknowledgment of the difference between "evil cults" (xiejiao - assimilated into the Western world's "cults") and "new religious movements" (xinxing zongjiao), thus perhaps opening the door to a gradual softening of the categories governing religions, ${ }^{(7)}$ as implied by the State Council's Regulations on Religious Affairs of March 2005.
The very nature of the institutional framework provided by the relay-associations harks back to a century-old practice, with the gradual constitution of "national" and "modern" religions: national religious associations took shape in 1912 and were coopted by the state in the $1930 \mathrm{~s},{ }^{(8)}$ albeit reformatted to suit the needs of the post 1949-regime. Thus the 1949 rupture did not dilute the constitution of a "modern" religious sphere that began in the late nineteenth century - but it is worth examining whether even the institutional rupture could be traced to a time far earlier than 1949 (to $1898^{(9)}$ ) in accounting for the dynamic of the Chinese religious phenomenon.

\section{Counting believers ...}

State control of religious expression does not accord with data collection. Thus, censuses preclude questions on religious affiliation. The Chinese opinion polling organisation Horizon Group (Lingdian jituan) conducted two surveys in collaboration with the Pew Global Attitudes Project in 2005 and 2006, and another in 2007 with C100, a non-partisan organisation of Chinese Americans. ${ }^{(10)}$ However, as city-dwellers are over-represented, ${ }^{(11)}$ the results reflect the

6. Published in March 1982, the Central Committee "Document 19" had already formulated the principles on which Article 36 is based.

7. See David A. Palmer, "Heretical Doctrines, Reactionary Secret Societies, Evil Cults: Labeling Heterodoxy in Twentieth-Century China," in Mayfair Mei-hui Yang (ed.), Chinese Religiosities: Afflictions of Modernity and State Formation, Berkeley, University of California Press, 2008, especially pp. 129-134.

8. This involved creating two competing Buddhist associations by 1912 , one more secular and the other monastic; a somewhat similar situation in Daoism's national structuring; creation of a national Islamic association; the flowering of a tentative national organisation for Confucianism; later national structuring of Christian churches, thanks to confessional divisions, foreign influences, and the strength of already existing specialised associations. See Vincent Goossaert, "Republican Church Engineering: The National Religious Associations in 1912 China," in Mayfair Mei-hui Yang (ed.), Chinese Religiosities: Afflictions of Modernity and State Formation, Berkeley, University of California Press, 2008, pp. 209-232.

9. See Vincent Goossaert, "L'invention des 'religions' en Chine moderne" (Invention of 'religions' in modern China), in Anne Cheng (ed.), La pensée en Chine aujourd'hui (Thought in China Today), Gallimard, Folio Essais, 2007, pp. 185-213; also Vincent Goossaert: "1898: The Beginning of the End for Chinese Religion?", Journal of Asian Studies, 65(2), 2006, pp. 307-336.

10. An account of the three surveys is available on pewforum.org, 2 May 2008. Analysis by Brian J. Grim, Pew Forum on Religion \& Public Life.

11. Studies on current changes in religious activities in the countryside are rarer. Given the difficulties faced by field studies, their conclusions have to be read with caution. Besides, Chinese researchers are at pains to explain what is behind the religious revival in the countryside, its significance and meaning, while agreeing that such a revival is a reality. Explanations advanced include: an organic link between economic growth and religious expansion; the rising strength of the "four numerous groups " (elderly, women, uneducated, and the sick and disabled) more susceptible to religious faith; the link between Western cultural influence and religious fervour; greater engagement by religions in the secular sphere; and confusion between religion and superstition. See Dong Jianbo and Li Xuechang, "Zhongguo nongcun zongjiao xinynag de bianqian" (Transformations in religious belief in the Chinese countryside), Shanghai Xinzhengyuan xuebao (Journal of Shanghai Administrative Institute), September 2004, 5 (5), especially pp.102-103. 
views of about half of China's adults. Six cities and their immediate surroundings were surveyed in 2005 and 2006, and seven in 2007. In the 2006 poll, 31 percent of those questioned said religion was "very or quite important in (their) life," with 11 percent affirming that it was "not at all important." The 2005 poll, with a somewhat differently framed question, produced a higher percentage (56 percent) of people who considered religion very or quite important to them. In the three surveys, between 14 percent and 18 percent of those polled admitted they subscribed to a religion. By way of comparison, another study by researchers from the East China Normal University in Shanghai, published in China Daily, ${ }^{(12)}$ showed that 31.4 percent of those aged 16 years and older, or about 300 million people, were religious. This finding was interesting because for the first time, a state-controlled media outlet cited a figure other than the one habitually trotted out, namely 100 million. ${ }^{(13)}$

The three surveys by the Horizon Group found Buddhists were the largest religious group in China - between 11 and 16 percent of the adult population. The surveys also confirmed the Chinese people's extreme reluctance to identify themselves as "Daoist": less than one percent of those polled said they belonged to that religion. Fewer than 4 percent of those polled said they were Christians. A hesitation to admit adherence to groups or churches that lack official recognition suggests that the real figures could be higher (the effect of over-representation of urban areas in the polls is more difficult to gauge). The questions in the 2005 poll included some on "personal belief" in "fortune" (yun) (40 percent of positive responses $\left.{ }^{(14)}\right)$, "Buddha" ( 8 percent) and "Lord Jesus (shangdi Yesu)" (6 percent). These responses do not seriously contradict others with regard to adherence: a higher percentage of people declaring themselves to be Buddhist might correspond to a positive appreciation of the morality system associated with Buddhism, which requires no faith in any particular figure. ${ }^{(15)}$ Meanwhile, belief in "Jesus" could go without declared adherence to any church. Considering the surveys' combined results and margins of error, it is conceivable that the figures are not unfounded. The polls, however, estimate those adhering to Islam at just below 1 percent, an under-estimation stemming from the surveys' geographic limitations. An estimation of adherence to Islam based on ethnicity figures gives a figure of 20 million to 23 million people - but this, too, is open to question.

A similar exercise in April and May $2005^{(16)}$ showed no difference between men and women in the interest shown in religion, nor any significant variation by age group. ${ }^{(17)}$ It also revealed a higher interest among city-dwellers (24 percent) than among rural folk (18 percent). (But the survey was probably limited to the immediate surroundings of cities and to people from rural areas living in urban areas). University graduates expressed much greater interest (26 percent) than those with diplomas from professional training colleges ( 18 percent). State and party officials expressed the greatest interest ( 33 percent). In terms of income level, the interest shown in the subject was almost identical among all categories, except for those with no fixed income (15 percent). Interest in religion is greater in the west of China than in the coastal provinces (30 percent in Sichuan, Qinghai, and Gansu, and 11 percent in southeastern provinces).

Ethnographers and historians might be concerned by such figures, pointing to the artificiality of the categories used, as well as other limitations inherent in the approach. However, their utility is undeniable, especially when the findings are combined with those from other disciplines. Below we will consider the methodological issues with regard to the constitution of the religious sphere. Meanwhile, this overview needs to be rounded off with some details on demography and changes in the particular forms that make up the world of religion.

\section{... and re-counting the faithful}

In any examination of the state of active religion in China, methodological problems over the precise breakdown of the number of believers and assessment of the social vitality of religious forms vary greatly according to the religion under consideration. In Islam's case, estimation of the number of believers is strictly correlated in all studies with that of members of ethnic minorities whose traditional religion is Islam. However, for Daoism or "popular religions" a breakdown is impossible, both in terms of practice and due to the very nature of the religious forms in question.

\section{7 February 2007 , chinadaily.com.cn.}

13. Of course, this figure, often repeated since the late 1990s, could hardly have been taken seriously, because Xinhua reported on 12 April 2006, for instance, that China had about 100 million Buddhists (xinhuanet.com. in English).

14. It is noteworthy that the 40 percent belief in chance or fortune (yun), which is considered "manipulable," is greater than that in destiny (ming) (29 percent), which is deemed more difficult to overcome.

15. Surveys in Taiwan have shown adherence to Buddhism (with little correlation between belief and practice) had weak correlation with Buddhist beliefs and practices. See Benoît Vermander, "Le paysage religieux de Taiwan et ses évolutions récentes" (Taiwan's religious landscape life and its recent changes), L'Ethnographie, 1995, 118, pp. 9-59.

16. Survey conducted by InterMedia. Data purchased and analysed by Pew. See pewforum.org, 2 May 2008. The question posed is subject to multiple interpretations: "Are you interested in the topic of religion and in the issue being discussed in the media?" A positive response indicates neither belief nor adherence to any religion.

17. By way of contrast, the East China Normal University survey reported in China Daily on 7 February 2007 found that two-thirds of those who said they were religous were aged between 16 and 39 . 

organisations go hand in hand with greater communication and solidarity among different centres, big or small, which in their entirety imbue Chinese Buddhism. In other words, Chinese Buddhism today may form a more robust and solid whole than it ever did in the past.

The nature and use of the monasteries' power, as exercised today by an elite group of young clerics immersed in the task of reconstruction and expansion, depends greatly on the transformation of the institutions' economic base. The exploitation of farmland has been replaced by greater dependence on donations (from abroad at first and then from local donors), help from government agencies (especially for building construction), rituals, tourism, and charitable activities. Generally, monks attached to a monastery receive a modest stipend, which they seek to complement through exercise of their liturgical talents or other means. In Tibetan monasteries, at least, benefits such as a stipend or lodgings are subject to the nature of the service rendered to the monastic community (upkeep of premises, teaching, accounting, archival ...). However, it would be difficult to understand the current state of Chinese Buddhism by looking at only two extreme situations - the beginnings as a monastic community, and the steady reconstruction of the past two to three decades. A word on the various manifestations over the past 150 years' history would be in order. The destruction during the Cultural Revolution was preceded by that during the Taiping rebellion (1851-1864), especially in southern China, the traditional bastion of Buddhism. Subsequent reconstruction coincided with a rise in internal criticism regarding the system of training and actual (non) respect of precepts. Chinese Buddhism was entering the era of aggiornamento. Some reformist monks essentially advocated a return to ancient disciplines, choosing to focus on a small number of texts and meditation practices. A little later, another line, whose most famous representative was the monk Taixu (1890-1947), undertook a modernisation of Buddhism modelled on the methods of early twentieth century Chinese republicans. The laity's role was assured. Monastic education, too, began following the Western university model. The establishment in the first part of the twentieth century of the Chinese Buddhist Association, the popularisation of a "humanist" or "worldly" Buddhism (renjian fojiao), contacts between monks and political leaders - all these elements influenced the image of Chinese Buddhism in the post-1980 era. At the same time, the debates that marked the 1870-1940 renaissance are to be found in the Buddhist community today as it relates to the post-modernity of a China caught up in ceaseless transformation.
Wutaishan is a good example of contemporary Buddhism's expansion as well as of the challenges it faces. In the mid1970s, this most celebrated of Chinese Buddhist templemountains was home to just a few hundred monks. By 2006 they numbered 5,000, and some restrictions were introduced on the number of monks and nuns in residence and as students. Official statistics show that 2.8 million people visited Wutaishan in 2008, yielding a tourist income of 1.4 billion yuan. The number of visitors is likely to top three million in 2009. ${ }^{(19)}$ The size and vigour of the community in charge of such an establishment, as well as the masses of people it attracts, makes Wutaishan a reference point for a large number of other communities that make up a social force much greater than their numbers might suggest.

Meanwhile, a note of caution regarding statistics: While retaining the figure of 9,000 temples for Han Buddhists alone, with some 70,000 monks attached to them, Christian $\mathrm{Co}_{-}$ chini's fieldwork conducted between 2002 and 2006 in 157 of the largest monasteries in China revealed much smaller monastic communities. ${ }^{(20)}$ Most places he surveyed had 20 to 200 resident monks or nuns, averaging between 60 and 80. Only some large educational centres (such as the Putuo temple and the Women's Buddhist Studies Institute of Wutaishan) have larger numbers resident. The majority of senior monks in the monasteries were born between 1955 and 1974. Since 1995, they have been replacing a generation born during the first years of the Republic or just before that. Most of them retain joint responsibilities in the national level Buddhist association or its provincial units.

\section{Catholicism between two heterodoxies}

In contrast to Buddhism, Catholicism's standing remains very much one of a "marginal" religion. The strength of identity of Catholic villages has often made them into entities isolated from the rest of their environment, equivalent to minority ethnic groups ("Catholicism as ethnicity," in Richard Madsen's words $\left.{ }^{(21)}\right)$. In cities, the network of Catholic schools and hospitals that could have given the church a high visibility functions in the margins of civil society and out of sight of the state apparatus. Madsen also describes contemporary Chinese Catholicism as being similar to a "heterodox reli-

19. Robert J. Saiget, AFP, 7 July 2009.

20. Christian Cochini, Guide des temples bouddhistes de Chine (Buddhist temples in China guidebook), Paris, Les Indes savantes, 2008. Guide to Buddhist Temples of China Macao, Macao Ricci Institute, Humanitas Publications Series, 2009.

21. Richard Madsen, China's Catholics: Tragedy and Hope in an Emerging Civil Society Berkeley, University of California Press, 1998, pp. 54-56. 
Front page of a liturgical Catholic calendar (year 2008).

It is written: "Let's pray for the Olympics".

(C) Taipei Ricci Institute

gion." (22) The flavour of "popular religion" that characterises Catholicism in the Chinese countryside gives it a cultural and social mooring, but risks alienating it from Catholic "orthodoxy" in the ecclesiastical sense. In other words, Chinese Catholicism is threatened by the label of "heterodoxy" in relation to both the Chinese regime and the universal church. This basic "heterodoxy" of Chinese Catholicism stems also from its longstanding roots. The intense cultural interaction between missionaries, the educated class, and the local populace from the late sixteenth century onwards took shape especially in the "ritual spaces" that constituted, for instance, funerals, and led to cultural syntheses that Nicolas Standaert has compared to evolving products of an "interweaving" in which different "threads" (texts, nature of ritual objects, musical and devotional practices, the calendar observed...) compose a symbolic text influenced by time and agency. ${ }^{(23)}$ At the same time, this analysis facilitates a nuanced appreciation of the marginality of Catholic communities. While they have acquired a strong identity, the often inventive and complex manner in which their rituals have evolved over time (for instance, funerals mixing elements of a diffused Chinese "religion" with practices expressing articles of Christian Credo) have helped establish "bridges" to other ritual communities. ${ }^{(24)}$ Chinese Catholic communities are distinctive, but they are no "strangers" to the forms and sensitivities of Chinese religiosity taken in its transversality.

Today, an analysis based on a series of estimates yields the figure of an official Catholic church of 5.3 million and an underground church made up of between 12 and 14 million. The level of "service" offered varies greatly, given that the official church has about 1,900 priests, and the clandestine church perhaps 1,200. The difference would be even greater for the number of adherents and seminarians. The number of baptisms announced by the dioceses appears to have risen in 2008 and 2009, especially in areas hit by the May 2009 earthquake. ${ }^{(25)}$ This growth should not divert attention from latent crises: rural Catholicism's future depends on the resistance of the type of sociability associated with this social structure. In cities, traditional Catholicism suffers from ongoing cultural changes. Mgr. Aloysius Jin Luxian, the Bishop of Shanghai, noted in a pastoral letter in December $2007^{(26)}$ the weak numerical growth of Catholicism compared to the Protestant churches. ${ }^{(27)} \mathrm{He}$ traced the cause to a lack of missionary zeal among the laity, who still regard evangelism as the domain of the clergy (priests and nuns). Meanwhile, the latter have been displaying a growing addiction to television and the Internet, according the bishop. The real issue here is the inadequacy of the classic parish model in a contempo-

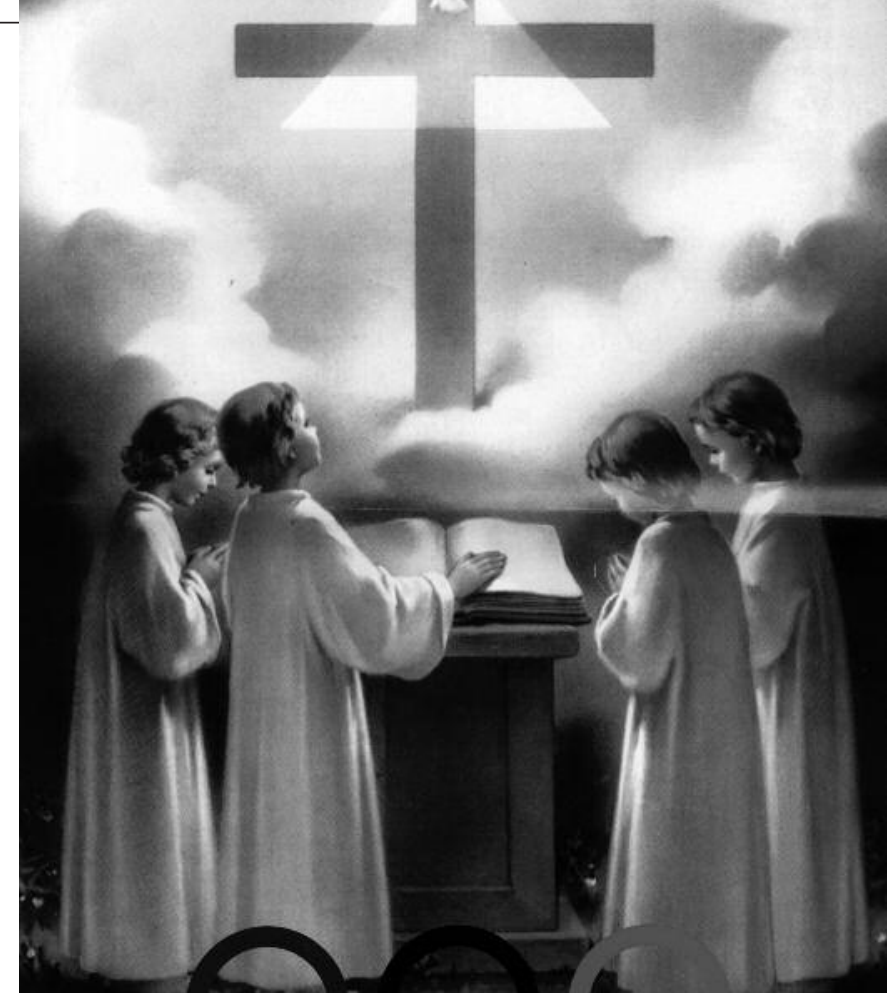

rary metropolis. Without minimising specific problems, it can be said that Chinese Catholicism is and will be increasingly affected by the crisis in governance and the societal model of the Catholic church as a whole. The distribution of powers and responsibilities between the faithful and clerics and the latter's standing, and the interpretation of Catholic doctrine between tradition and modernity, are debates that will also influence the vitality and relevance of the Chinese church.

22. See Richard Madsen, "Beyond Orthodoxy: Catholicism as Chinese Folk Religion," in Stephen Uhalley, Jr., and Wu Xiaoxin (eds.), China and Christianity: Burdened Past, Hopeful Future, Armonk, NY, M.E. Sharpe, 2001, pp. 233-249.There are a number of connotations of the expressions xiejiao and xiedao. The character xie refers to all that is perverse, unregulated, heterodox, or pernicious. In Chinese medical terms, it denotes mainly exogenous pathogens. Although different schools of thought often trade such expressions, xiedao and xiejiao are epithets the Confucians first used for Buddhists and, from the seventeenth century, for Christianity, "heterodoxy" more or less standing for subversion of intellectual tradition and political status quo.

23. Nicolas Standaert, The Interweawing of Rituals: Funerals in the cultural exchange between China and Europe, Seattle, University of Washington Press, 2008, pp.214-222.

24. Ibid., pp. 222-228.

25. China heute (China Today), 2009, 1 (161), pp.7-10. Baptism statistics (valid for the official church only) are compiled by the Hebei-based Catholic weekly Xinde (Faith) and are incomplete. Figures from 90 dioceses in 2009 show 22,000 baptisms between January and April, a 14 percent rise over the previous year, with a strong growth in Chongqing and Chengdu. Xinde, 22 April 2009, p.1; Ucannews, 28 April 2009.

26. English text in Tripod, vol. XXVIII, no. 149, Summer 2008, pp. 5-19.

27. Before 1949, Protestant churches had about 30,000 adherents in Shanghai. By 2007 they numbered about 200,000. During this period, the Catholic church saw its strength rise from 100,000 to just 150,000 . (Ibid., p.13). The pastoral letter speaks of "incomplete statistics," but the figure no doubt includes some clandestine churchgoers. The difference is smaller than the gross figures might show, but the Protestant churches enjoy clear numerical superiority. 


\section{Protestantism: A Chinese religion on the rise?}

"One is tempted to speculate that while Catholicism is a way for rural people to shelter themselves from modernity, Protestantism is a way to strengthen and fortify them as they undertake a dangerous pilgrimage into modernity," Madsen has observed. ${ }^{\left({ }^{(28)}\right)}$ The statement errs through over-systematisation. Nevertheless, Chinese Protestantism exudes a feeling of empowerment and strong self-confidence, which the faithful seem to display in daily life. In addition, lively networks largely transcend territorial limitations.

Estimates of the number of Protestants in China vary between 20 and 130 million, with Chinese officials themselves citing conflicting figures. There are many varieties of groups and modes of adherence in a configuration that in some ways resembles the "nebulous" nature of Daoism and Buddhism - all of which makes Protestantism an authentically Chinese religion. However, a more or less credible estimate is not too difficult to reach, and the crosschecking of data sheds some light. Based on fieldwork in all provinces except Tibet, Werner Bürklin of China Partner arrived at an estimate of 39 million Protestants in 2007, equally divided between recognised and unrecognised churches. The figure is close to that of the East China Normal University. ${ }^{(29)}$ Even if the figure is an underestimate, as many evangelical associations claim, it is based on more rigorous data than others. Protestants and Catholics would thus make up 4 to 5 percent of China's population.

The distribution of churches does not represent a simple division between local communities affiliated with the ThreeSelf Movement and others deemed clandestine. Don Snow has suggested grouping the churches into five categories: ${ }^{\left({ }^{(3)}\right.}$ (a) local congregations registered with the Chinese Christian Council and the Three-Self Patriotic Movement; (b) legally registered congregations that, however, do not gather in a church but in houses or other structures; (c) groups affiliated with a foreign denomination (Seventh Day Adventists) or those claiming Chinese origin, groups that often meet alongside other congregations and come together to register their places of worship with the local office of religious affairs; (d) "house churches," mostly in cities, that have deliberately chosen not to seek recognition from officially approved Protestant organisations; and (e) largely unregistered rural groups, often with a syncretic orientation and enterprising leadership. Should the "prudent" estimates of Protestant numbers turn out to have been too low, it would be a function of underestimating the vitality of these congregations.

Bürklin's fieldwork and data from, among others, the Amity
Foundation, ${ }^{(31)}$ also suggest a regional typology, with the largest Protestant communities in Henan, Anhui, Zhejiang, Fujian, Guangdong, Jiangsu, Shanxi, and Shaanxi. This geographic distribution should be seen in relation to the types of churches, with special attention to the main unregistered groups such as the Shouters (Huhanpai), Way of Resurrection (Fuhuodao), and Society of Disciples (Mentuhui). The number, variety, and doctrinal inventiveness of such groups is undeniably a striking feature of the Chinese religious domain. In several respects, these groups may seem successors of the "heterodox cults" of previous centuries. A sharper appreciation of their regional roots would no doubt suggest revealing links that fix contemporary Protestantism in Chinese religious history.

If this analysis were extended to Daoist associations, to manifestations of popular religion, to the rites and beliefs of minority nationalities, and to new or para-religions, the conclusion would only be strengthened: the undeniable vitality of the Chinese religious scene goes hand in hand with the multiplicity of communal forms and degrees of adherence. They combine a marked "localism" with tendencies observable globally; institutional religious forms find their place in Chinese society while continuing to maintain complex relations, buffeted by and ill at ease with the structures of the partystate. Institutional, demographic, and confessional studies lead quite naturally from a study of "Chinese religions" to an attempt to interpret "China's religious domain" in its entirety.

\section{Logic of the religious}

The specificities of the Chinese case do not mean that, in principle, the categories of Western religious sociology are not applicable. A new generation of Chinese sociologists has even argued for their relevance, if only to sharpen or enrich their usage. ${ }^{(32)}$ They have thus made a break with C.K. Yang's generation, which applied to Chinese religions more general categories from the sociological tradition than those of religious sociology in the strict sense. ${ }^{(33)}$ Meanwhile, it is

28. Madsen, op.cit. p. 138.

29. See. www.assistnews.net, www.chinapartner.org.

30. In a contribution first published in China News (Update), March 2003, and reproduced in http://www.christianityinchina.org.

31. http://www.amitynewsservice.org.

32. See Yang Fenggang, Joseph B. Tamney (eds.), State, Market, and Religions in Chinese Societies, Leiden, Brill, coll. "Religion and the Social Order," 11, 2005.

33. While Joachim Wach is associated with the famous distinction between informal and institutional religions, the initial concept can be traced to Talcott Parsons, as C.K. Yang has indicated in his brief preface. See Religion in Chinese Society, Taipei, SMC Publishing, 1994 (1961), pp. iii and 294. 
true that both the methods of the sociology of religions and Chinese religious life have evolved considerably.

\section{A fragmented market for religion}

Among these attempts, one merits detailed consideration: using a schema developed by Stark and Finke, ${ }^{(34)}$ Yang Fenggang applies the "religious market" theory to contemporary China ${ }^{(35)}$ - one featuring a range of activities, real and potential adherents, organisations seeking long-term adherence and control of adherents, and a religious culture offered by these organisations. A country's market is influenced by the degree and modes of regulation or deregulation of the religious sphere adopted by the state, the interaction between market and regulation norms creating a religious economy.

Yang's main thesis is that the type of regulation adopted by the Chinese state has led to the constitution of three religious markets (or to the fragmentation of the combined religious market into three specific ones), which he labels "red," "black," and "grey." The red market includes organisations, beliefs, and activities enjoying state approval and obeying its directives. The black market is the exact opposite of the first, operating illegally. The grey market is defined above all by the legal ambiguity of its operation. It can be divided into two sub-combinations: (a) illegal activities of legally recognised organisations (evangelism carried out house-to-house or under cover of social services provided by groups under the Protestant or Catholic patriotic associations, for instance); (b) religious activities carried out under other pretexts, such as scientific or cultural (quasi religions, "folkloric," popular or "health" practices, reconstruction of temples, or resurrection of traditional religious forms in southeastern China). Restrictions on the red market and dangers associated with the black market inevitably lead to growth in the grey market, Yang says. He sees the premise of this in the Mao cult during the Cultural Revolution and initial expression in the qigong fever. ${ }^{\left({ }^{36}\right)}$ Yang even hazards some estimates: 100 million participants in the red market, 200 million in the black market and "several hundreds of millions" of potential adherents in the grey one, constituting the target audience for the rebirth of informal religions and no doubt for new religious movements should they succeed in gaining public expression. ${ }^{(37)}$

Yang's analysis of "Chinese religious economy" suffers from being reduced to the dimension of mere individual actors on the one hand and the state on the other. It also suffers from an excessively elastic definition of the "grey market." However, it gives a good account, for instance, of the individual strategies of Falun Gong adherents and members of qigong groups after 1999; qigong's passage into the black market for practitioners willing to pay the price of their determination; the retreat from the religious market for others; entry into Christianity or Buddhism for others; and the slow and cautious reconstruction of a new "grey market" segment through the recognition of qigong fitness associations (jianshen qigong). The religious economy approach also helps conceptualise the Chinese paradox: on the one hand there is a major fragmentation of religious expression caused by the mode of state regulations; but on the other, it is worth apprehending the fact of Chinese religiosity in its continuity, the choices made by individuals turning out to be (a) fluid in their expression, according to the price they have to pay to satisfy their latent demand and according to the changes in regulations and their application; and (b) constant in terms of "expressed needs," even though the price imposed by the state governs the level and mode of religious consumption. ${ }^{(38)}$ Pursuing this analysis, the question arises whether the religious market is itself included in a larger "market of meanings" in which nationalism, "national studies" (guoxue), sport, and art would constitute other expressions. Each would be in competition with others and justifiable in terms of the cost in relation to the derived satisfaction, in its turn defined through the conviction to lead a personal life in relation to the destiny of the group (natural collectivity, nation, church, humanity... $\left.{ }^{(39)}\right)$. The state's attempt to control the "market of meanings" through the slogan of "spiritual civilisation" (jingshen wenming) has led to growing exasperation on the demand side caused by inadequate supply. At the same time, strictly religious responses to this social demand could prove too costly for some actors. Or they might not fully meet the expectations aroused, or further, lose value rel-

34. Rodney Stark and Roger Finke, Acts of Faith: Explaining the Human Side of Religion, Berkeley and Los Angeles, University of California Press, 2000.

35. Yang Fenggang, "The Red, Black, and Grey Markets of Religion in China," The Sociological Quarterly, 47 (2006), pp. 93-122. The author has published a Chinese version of the article: "Zhongguo zongjiao de san se shizhang," Zhongguo renmin daxue bao (Journal of Renmin University of China), 2006 (6), pp. 41-47.

36. Art. cit., pp. 98-99.

37. Art. cit., pp.113-114.

38. Yang has not considered the issue of a possible rise in "global demand" after the satis faction of material needs, or of a demand fluctuation as a function of private and public cycles similar to those propounded by A.0. Hirschman in Shifting Involvements, Private Interest and Public Action, Princeton University Press, 1982.

39. Paul Tillich was one of the first to thematise the inclusion of historic religions in the sphere of meaning that modernity has extended to "secular quasi-religions." "Religion" in its most extended meaning thus corresponds to "the state of being seized by an ultimate concern" that responds "to the question of our life's meaning." See Le Christianisme et les Religions, Paris, Aubier-Montaigne, 1968, pp. 65-68. 
ative to competition from new vectors of supply, the "national studies" vogue representing one example of that trend.

\section{Towards an integrated religious economy}

The question that arises at this point is whether the market paradigm sufficiently accounts for the basic phenomena determining China's "religious" sphere or whether other paradigms could substitute for it partly or wholly. For the rest, most ethnological studies do not give primacy to the individual agent in China's religious market as a whole, however it might be governed by state regulations. Individual actors' behaviour and choices are in general mutually correlated spheres. Curiously, it is the attention given to traditional structures of local "markets," their networking, the resilience of trading communities and culturally endogenous communities, ${ }^{(40)}$ which gives rise to "belief spheres," often linked to matrimonial alliances and "ritual spheres" (jisi quan ${ }^{(4)}$ ). The latter are difficult to describe, as they include pilgrimage centres often far from local networks. In Skinner's approach, the "sphere" by definition surpasses the village framework. But in subsequent usage, the term is often applied to any cultural unit that can be shown to be structured and relevant, including (perhaps) the village. ${ }^{(42)}$ Nevertheless, it is applied more exactly to a nexus intersecting a number of communities according to a system of often complex alliances and interests. Even in this case, the sphere is primarily spatial in the sense that it raises the limits of a symbolic territory, delimited and often protected by the object and form of ritual practices.

At first glance, the description of these spheres induces apprehension of the religious sphere in terms that leave little room for the market paradigm. This is not because the individual has a mere subordinate role, but because the range of adherences, beliefs, and religious practices is highly limited and boxed in - so much so that religious inventiveness and adaptation to global changes are manifested less by replacement of one "product" by another than by a logic of internal adaptation, which often brings about profound changes to the available religious supply without changing the original configuration. It is a corporatist economy of the religious described as a "sphere" or "field."

Meanwhile, it is worth noting that the attention to "belief spheres" could take into account phenomena of conversion. Attention could focus on their collective character and the manner in which conversion reinforces the local sphere and renders it more dynamic. This, in turn, making a similar leap, reworks its identity markers and symbols rather than abandoning them. This phenomenon is illustrated by the diverse forms of rebuilding rural religious life after the Cultural Revolution, such as Thomas DuBois has described with regard to a county in Hebei. ${ }^{(4)}$ The village may have an intense or limited religious life, or it may house a temple or serve as a centre for a dominant religious group descended from "heterodox" cults of previous centuries. In all these cases, (conversion from one religion to another, mode of rebuilding the village religious identity by reinterpreting ancient systems), a religious choice is made, but it may seem to be the result of collective rather than individual choice. It is the mode of interaction in the village community and the type of needs to be satisfied ${ }^{(4)}$ that would be decisive factors of religious reconfiguration.

Ultimately the following schema might be attempted: collective actors such as the village, the guild, or devotional associations created a primary "religious market" that long served as the dominant market. This once suppressed market is now seeking its proper place. The actors negotiated the price of religious intermediaries, ${ }^{(4)}$ and left little place for a market of individual actors. There was some elasticity in the forms and cost of religious services within the market segment in which they operated. Conversely, the change from one religious form to another (conversion of a village to Christianity, for instance) took place at a heavy cost - at any rate, existing alternatives were limited. Meanwhile, there was always a second religious market activated by individuals (or by families independent of the compulsions of the vil-

40. G. William Skinner, "Marketing and Social Structure in Rural China," Journal of Asian Studies 241 : 3-43, 24 (2): 195-228, 1964.

41. See Lin Mei-jung, "Ritual sphere as local organisation form: The case of Caodun agglomeration" (You jisi quan lai kan caodun zhen de difang zhzhi), Bulletin of the Institute of Ethnology, Taipei, Academia Sinica, no. 62, Autumn 1986, pp. 53-114.

42. See the classic study by Stephan Sangren, History and Power in a Chinese Community, Stanford, Stanford University Press, 1987; David Faure, The structure of Chinese Rural Society: Lineage and Village in the Eastern New Territories, Hong Kong, Hong Kong and Oxford University Press, 1986. Burton Pasternak, among others, has shown that village rituals may or may not be factors of community cohesion and that many factors determine the place and importance of these local rituals (see Kinship and Community in Two Chinese Villages, Stanford, Stanford University Press, 1972, especially pp. 109-113 and 125-127). In other words, the first question the ethnographer poses is the extent, relevance, and correlation of ritual or belief spheres, without presuming the basic primacy of this or that territorial dimension.

43. The Sacred Village: Social Change and Religious Life in Rural North China, Honolulu, University of Hawaii Press, 2005, pp. $39 \mathrm{ff}$

44. Again, these needs may be diverse: insufficient rains, the place accorded to lineage, the local health situation, or the intensity and prevalence of conflicts could weigh heavily on the hierarchisation of symbolic needs.

45. On the variation in the remuneration of religious intermediaries as a function of supply and demand, and the limited elasticity depending on the community in question, see the examples offered by Donald S. Sutton, "Transmission in Popular Religion: The Jiajiang Festival Troupe of Southern Taiwan," in Meir Shaharr and Robert P. Weller (eds.), Unruly Gods: Divinity and Society in China, Honolulu, University of Hawaii Press, 1996, pp. 220 221, and Thomas DuBois, op. cit., pp. 61, et. al. 
lage or lineage). Affiliation with a "heterodox cult," for example, typically occurs on an individual basis; ${ }^{(46)}$ "entering monastic life" (chu jia) was an alternative choice, migrations accompanied changes in religious affiliations, and the process is still ongoing... Chinese "religious economy" functioned (and still does after a fashion) through multiple forms of interaction among three actors: the state, at once market regulator and itself in possession of a religious or quasi-religious "supply"; a group of collective actor-regulators of rituals; and individual actors prone to desert one segment of the market and set up another. Chinese researchers often assert that the individualisation of actors is the most notable feature today, and that it is accompanied by the entry of religious activities into the market mechanism, the modernisation of religious beliefs and attitudes, and a peaceful competition between different beliefs and organisations. ${ }^{(47)}$

\section{"Exit from Religion" with Chinese characteristics}

At this stage, it is possible to return to the use of the term "religious": does it gloss over the realities of the prefabricated categories under examination, thus blocking rather than promoting understanding?

Societies where the state has taken shape are those where the separation of the politico-state sphere from the religious sphere has taken place. Such, at least, is the famous thesis of Marcel Gauchet. Space precludes discussion of all of Gauchet's presumptions and their implications, but a few elements may help shed new light on the structuration of the religious sphere in China. If religion is understood as the operation through which a human group relates its existence to a foundation outside of itself and on which it has no hold other than through rite of magic (or further, as Gauchet says, "humanity's relation with itself under the sign of dispossession" ${ }^{(48)}$ ), the birth of politics (wherever it is not prohibited through virtual choices made within "state-less societies") progressively operates the limitation of the religious sphere by instituting a series of mediations of society with itself. With the rise of the state "starts a materialisation of religious exteriority in the collective space." ${ }^{(49)}$ Later, with the formation of the modern state ("the state in possession of its concept"), "by separating from religion, politics came to light and became identifiable in and of itself." ${ }^{(50)}$

In this light, "the revolution of exit from religion" is that of "the political condition taken on consciously." (51) In other words, "exit from religion" corresponds to the condition of a group as a community capable of determining its mode of ex- istence and its destiny solely based on the mediations imposed by rules of political discussion, without the interference of sacred reference. Of course, in China, the arrival of the political condition did not occur along the path and timeframe that characterised the Western experience. This divergence is concomitant to that observed in the structuration and evolution in the religious sphere. But the appearance, even if virtual, of the political condition cannot but provoke the march towards a religious "specialisation" and eventual loss of the religious sphere's social effectiveness as basis of the social bond itself. ${ }^{(22)}$ While the precocious appearance of the Chinese state quickly subordinated the religious function's social expression to China's own political forms, these same political forms, for a very long time, preserved the sacred basis of the social sense of togetherness. In this light, it is no doubt inaccurate to describe the development of the late nineteenth century as a "rupture" that artificially tipped the Chinese "religious" sphere into Western-style "religion," overhauling the ethos of the former. Rather, all the historical stages preceding this moment (the emergence amid the ruins of the Han dynasty of Daoism and Buddhism as "specialised" constituted religions, the rupture of traditional solidarities induced by the periodic formation of "heterodox cults," Confucianist reformulations, Rites controversies, anti-clerical crystallisations...) could be seen in continuity. In its long history, China has clearly experienced a gradual structuration of the religious sphere, signalling a distinction between the religious and other domains of social activity. Not only are Chinese religions subject to perpetual change, redefinition, and autonomisation historically, but their involution confronts them today with the question of the "exit from the religious sphere" in its global expression. In other words, the Chinese state has, throughout its long history, mobilised and constantly reformulated existing religious resources in such a manner as to create and perpetuate both the self-representations of the body social and the state's own control over it. This fact should not prevent a diachronic reading of the emergence of China's own au-

46. See the account of the Li sect's implantation in Tianjin in the 1930s in Thomas DuBois, op. cit., pp. 113-121.

47. See Hu Changshen "21 sheji zhongguo zongjiao de yanbian qushi xintan" (New studies on religious tendencies and transformations in twenty-first century China), Zhonghua wenhua luntan (Chinese Cultural Forum), 2002, 1, pp. 31-34.

48. Marcel Gauchet, La condition politique, Paris, Gallimard, "Tel," 2005, p. 14.

49. Ibid., p.17.

50. Ibid., p.19.

51. Ibid., p.20.

52. This is precisely what the Chinese religious sphere's diffused character has achieved. 
tonomous religious forms and debates, which gradually weakened the politico-religious link taken as the sacred basis of social life. As in other social contexts, the weakening of such a link facilitated the Chinese national community's entry into the "political condition" in the same movement through which it effected its "exit from the religious." This process is far from and might never be complete. However, understanding it remains important in order to avoid the temptation to analyze Chinese religious evolutions only in terms of "external ruptures" that took place during the last 60,100 or 150 years.

\section{Contemporary Confucianism: True religion of the exit from religion?}

Contemporary Confucianism offers an example of what is at stake here. By the late nineteenth century, the spread of Western knowledge, epistemological categories (science, religion, politics), and social institutions (universities, churches, the press, and parties) challenged Confucianism's self-image as a complete ritual, sapiental, and cosmological system as well as the foundation of China's social and cultural order. ${ }^{(33)}$ Attempts to save the universality of Confucian teaching (jiao) were followed by its republican reformulations, either as religion (conceived in relation to and contrasting with Christianity, religion's epistemic model), or as philosophy, again in a tense relationship with Western tradition. After the Maoist storm, Confucian "reconstruction" in parallel and competing with religious reconstruction passed through different stages and strategies. Researchers have found the vitality of a "popular Confucianism" organised around temple lineages (citang), serving as providers of continuity and communal harmony. The rise of China and the Asian Tigers has stoked lively debate over the socio-economic effectiveness of Confucian wisdom. The national, even nationalist, affirmation has taken the form of a still growing body of reinterpretations of the Confucian canon, addressing varied publics but aimed at a still larger fringe of the Chinese population. A corollary question arises of Confucianism's "religious nature": a number of systems are flourishing with the aim of clarifying its ultimate nature and social function and its desirable incorporation into legal structures. The essential aspect of this deep-seated movement for social and intellectual reconstruction is that it is offered as an alternative to the Western categories that had triumphed in the late Qing period. It also questions the demarcations erected between science, philosophy, wisdom, and religion, ${ }^{(54)}$ the university's monopoly over dispensation of knowledge, and the functionalisation of a political space conceived independently of the national tradition it inhabits.

These scattered and inchoate attempts are meant to assert Confucianism's religious value and at the same time contest the way in which the West has imposed on China's ancient social and cosmological order its own divisions of different levels of existence and knowledge. It is a contemporary reformulation that clearly would not lead to the revival of a bygone and largely imagined past, but the question is whether it would not install Confucianism as the Chinese religion of the exit from religion to the extent that Confucianism is meant to anchor the social link in transcendence. ${ }^{(5)}$ This transcendence is inscribed in an interpretation of Chinese national and cultural history combining the specificity of its humanist contribution and the demand for a kind of universal knowledge of the nature of man and his capacities to surpass himself. But it is a religion of the exit from religion to the extent that the Confucian model of knowledge and action contests the distinctions established by the West (and even by the Indian world) among sciences, religion, and other domains of social practice on the one hand, and the forms and meanings of rituals commonly qualified as "religious" on the other. It is therefore the synthesis already suggested in his time by Confucius (criticism of the religious accompanied by an accommodation to it), and reformulated after the intellectual encounter with the West, paradoxically projecting Confucianism in the era of post-modernity. In this logic, whereas Christian tradition had led to a long and tiresome route through its forms and its essence to an "exit from religion," Confucianism overcame right from its first principles the historic stage of "the religious as the basis of social relationship." This was accomplished while furnishing meaningful resources to maintain a quasi-sacred basis of social relationships - something the post-modern West is not yet able to ensure.

\section{The instrumentalisation of religion}

Another example of "the exit from religion" in China is paradoxically provided by the appeals made to religions by the rulers and the ruled. The henceforth total absence of a basis

53. This synthesis is inspired by Sébatien Billoud and Joël Thoraval, "The Contemporary Revival of Confucianism: Anshen liming or the Religious Dimension of Confucianism," China Perspectives 2008 (3), pp. 88-106.

54. Although it may mean borrowing Western epistemological reconstructions such as those of Ilya Prigogine. See S. Billoud and J. Thoraval, art. cit., p. 108

55. The issue of Confucianism's religious nature has led to innumerable debates. For an account of the issues since 1978 it would be worth consulting John Makeham, Lost Soul: "Confucianism" in Contemporary Chinese Academic Discourses, Cambridge, Harvard University Asia Center, 2008. 
transcending the social (a basis that Maoism had sought to promote) makes religions into auxiliary dispensers of a "harmony" they can no longer ensure through their rituals and social mooring. Failing that, religions "fabricate" harmony in the style of a theoretical "construct," i.e., of a reinterpretation of their traditions guided by the imperatives of a regime concerned with better managing ongoing social transformations. Thus, some scholars have suggested that it would not be absurd to speak of a "conversation" in the long run between Protestant and state-party leaders. ${ }^{(56)}$ Protestant churches' preoccupation right from the Republican era with participating in the construction of a modern state, the personality and influence of bishop K.H. Ting, ${ }^{(57)}$ details of negotiations as to methods of managing religious affairs after 1980, and the theological construction around notions of harmony or of socialism, show an intensity of interaction that has also contributed to the Chinese state's modernisation. At the same time, it is precisely this intensity that has heightened Chinese Protestantism's internal divisions. It is an example of the reinterpretation and secularisation of religious doctrines in line with national contexts. Such an analysis could apply, for instance, to the constructions of renjian fojiao (worldly Buddhism) to the extent that it offers a mode of civility attesting to the social relevance of the tradition thus reinterpreted.

Thus the forms that Chinese religious revival takes often equate to nostalgia for the politico-religious basis of social relationships - religions today being susceptible to instrumentalisation precisely because religion does not offer the sacred anchoring for communal life. From this fact alone, the religious revival in China may be interpreted in terms of a historic transition: of the country's hesitation on the threshold of an autonomisation of politics - such is the abiding strength of efforts to anchor social relationship in a sacred reference.

In a context marked by both continuing state control and the state's lost hold over forms and categories of the religious sphere, the religious burgeoning is both a possible prelude to and present substitute for democratisation (or at any rate, autonomisation of civil society). The growing instrumentalisation of Chinese religions is accompanied by the loss of all religious basis for social relationships, ushering China into the era of "exit from religion," although such a process remains unfinished and contradictory. Protestantism and Buddhism, among other religious expressions, now entertain ambitions to serve as the local and global expressions of a religious sphere that is no longer the foundation but rather the auxiliary to social relationships. At the same time, a recon- stituted Confucianism aspires to become the complete religious form of the exit from religions. Clearly, the study of religious changes in China today is more than a simple ethnographic exercise. When put into context, it can provide a valuable contribution to our understanding of evolving forms of communal life in national societies facing the emergence of a global community whose unique foundation is the destiny it decides for itself. •

\section{- Translated by N. Jayaram}

\section{Glossary}

chujia 出家 citang 祠堂 fang 放 fensanxing 分散性 fuhuodao 復活道 guiyi 的依 guoxue 國學

hanyu shenxue 漢語神學 hehe 和合 hehexue 和合學 hexie 和諧 huhanpai 呼喊派

jianshen qigong 健身氣功 jiao 教 jingsheng wenming 精神文明 jisi quan 祭祀圈 jushi 居士 kuosanxing 擴散性 lixue 理學 mentuhui 門徒會 ming 命 misanxing 彌散性 qishi 啟示 renjian fojiao 人間佛教 sankaide 散開的 shangdi yesu 上帝耶穌 sheng sheng bu xi 生生不息 shou 收 wu 悟 xiedao 邪道 xiejiao 邪教 xinxing zongjiao 新興宗教 yiguandao 一貫道 yun 運 zhihui 智慧 zhizhe 智者

56. See Ryan Dunch, "Christianity and 'Adaptation to Socialism,'” in Mayfair Mei-hui Yang (ed.), Chinese Religiosities: Afflictions of Modernity and State Formation, Berkeley, University of California Press, 2008, pp 155-178.

57. On the central figure of K.H. Ting, see the exhaustive study by Philip L. Wickeri, Reconstructing Christianity in China: K.H. Ting and the Chinese Church, Maryknoll, New York, Orbis Books, 2007. 